www.nature.com/bmt

\title{
CORRIGENDA
}

\section{Contemporary analysis of the influence of acute kidney injury after reduced intensity conditioning haematopoietic cell transplantation on long-term survival}

\author{
JA Lopes, S Gonçalves, S Jorge, M Raimundo, L Resende, F Lourenço, JF Lacerda, C Martins, \\ JA do Carmo, JMF Lacerda and MM Prata
}

Bone Marrow Transplantation (2008) 42, 635; doi:10.1038/bmt.2008.341

Correction to: Bone Marrow Transplantation advance online publication, 14 July 2008; doi:10.1038/bmt.2008.207

In this article published online and also in this issue, the authors wish to make a number of changes to the text under the section heading Reduced intensity conditioning regime and HCT procedure.

The corrected text is as follows:

\section{Reduced intensity conditioning regimen and $\mathrm{HCT}$} procedure

The conditioning regimen for related HCT consisted of fludarabine $\left(30 \mathrm{mg} / \mathrm{m}^{2} /\right.$ day for 5 days $)$, thymoglobulin (2-5 mg/kg/day for 4-5 days, with i.v. continuous perfusion during $24 \mathrm{~h}$ ), prednisone $(2 \mathrm{mg} / \mathrm{kg} /$ day for $4-5$ days $)$ and melphalan $\left(60 \mathrm{mg} / \mathrm{m}^{2} /\right.$ day on days -3 and -2$)$. For patients undergoing unrelated $\mathrm{HCT}$, melphalan $(70 \mathrm{mg} /$ $\mathrm{m}^{2}$ /day) was given on days -3 and -2 , and cytarabine $\left(2 \mathrm{~g} / \mathrm{m}^{2} /\right.$ day, with i.v. continuous perfusion during $\left.12 \mathrm{~h}\right)$ was also given on day -8 . The patients received haematopoietic cell grafts from HLA-matched related or unrelated donors derived from either peripheral blood or BM on day 0 . All patients received GVHD prophylaxis with CYA and mycophenolate mofetil. CYA was started on day -1 at $5 \mathrm{mg} / \mathrm{kg}$ twice daily and continued until 3-6 months, followed by tapering, if no GVHD was present. Trough levels of CsA were targeted at 180-380 ng/1. Mycophenolate mofetil was started and continued at $1 \mathrm{~g}$ twice daily until 1-3 months. GVHD treatment consisted of methylprednisolone and resumption of $\mathrm{CsA}$, if already tapered. Infection prevention consisted of ciprofloxacin and fluconazol until granulocyte counts exceeded $500 \mathrm{cell} / \mu \mathrm{l}$, and fluconazol was given for 3 months, unless GVHD was diagnosed, in which case fluconazol was continued for at least 6 months. Cotrimoxazol $960 \mathrm{mg}$ on alternate days was given for 12 months, and acyclovir $500 \mathrm{mg} / \mathrm{m}^{2}$ three times a day was given on the first 30 days. Then, it was continued at $200-800 \mathrm{mg}$ twice daily for 6 months, unless GVHD was diagnosed, in which case acyclovir was continued for at least 12 months.

The authors apologize for any inconvenience caused.

\section{Successful outcome of allo-SCT in high-risk pediatric AML using chemotherapy-only conditioning and post transplant immunotherapy}

\author{
S Bonanomi, P Connor, D Webb, P Ancliff, P Amrolia, K Rao, D McCloskey, S Hemmatpour, \\ $\mathrm{N}$ Goulden and P Veys
}

Bone Marrow Transplantation (2008) 42, 635; doi:10.1038/bmt.2008.342

Correction to: Bone Marrow Transplantation (2008) 42, 253-257; doi:10.1038/bmt.2008.160
The author name S Bonanomi was published incorrectly in the above referenced paper. The correct author list is shown above. 